\title{
Calcium Propionate Increased Milk Parameters in Holstein Cows
}

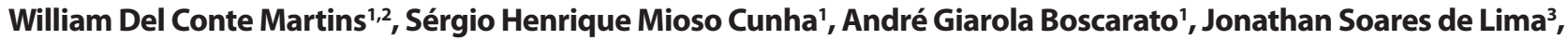 \\ Jair Dario Esteves Junior ${ }^{3}$, Gian Carlo Uliana ${ }^{3}$, Mateus Pedrini ${ }^{3}$ \& Luiz Romulo Alberton'
}

\begin{abstract}
Background: In the early lactation, dairy cows go through a period of negative energy balance because they do not intake enough food to supply the energetic demand of milk production. In this period, dairy cows are susceptible to metabolic disorders, although has little evidence that milk production contribute to increase diseases occurrence. Some alternatives to minimize metabolic disorders, that reduce milk yield, has been suggested, as increase energy density in the diet of dry cows 21 days before the parturition and include additives in the diet pre and post-partum. The aim of this study was to measure the productive parameters in dairy cows fed calcium salts as energetic source.

Materials, Methods \& Results: Two Latin square 4x4 were used, whereas one comprehended of early lactation cows and the other of mid lactation cows. Animals of $2^{\text {nd }}$ and $3^{\text {rd }}$ parity were used only. Parity was distributed evenly among groups. The trial consisted of 4 groups with 4 treatments as follow: T1: $300 \mathrm{~g}$ of calcium acetate, T2: $200 \mathrm{~g}$ of calcium propionate, T3: $200 \mathrm{~g}$ of calcium salts of fatty acids, and T4: control without any calcium additive. The animals were milked twice a day, the first milking at 07:00 am and the second milking at 05:00 pm. Milk samples were collected in plastic containers with potassium dichromate. These samples were sent to the Laboratory of Milk Analysis of the Paranaense Association of Breeders of the Holstein Breed for analysis of fat, protein, lactose and total solids through the infrared method. Throughout the experimental period, the daily production of the animals under study was recorded. The production of milk $(\mathrm{kg})$ was corrected to $3.5 \%$ fat using the formula PLA $3.5 \%=(0.432+\mathrm{kg}$ milk $)+(0.1623 \times \mathrm{kg}$ milk x fat content $)$

Discussion: Greater supply of glucose or propionate stimulate milk protein production, but the mechanism of this stimulation is unclear. Milk protein is dependent on energy supply, and deficient energy intake reduces milk protein levels. Calcium propionate provided enough energy supply and increased milk protein levels. The synthesis of lactose has influence in water absorption in mammary gland and lactose determine milk osmolarity. The lactose levels vary according blood glucose, somatic cells count and energy availability for physiological processes. In the literature, rarely has been found greater lactose concentration caused by feed intake, becoming very important the results found in this work. The diet energy concentration and consumption rate determine energy intake, which limit milk yield. Dairy cows in early lactation has marked increased of nutrient requirements to support milk production. Support milk lactose synthesis in the mammary gland is the one of responsible for increase of nutrients requirements. In this period, the glucose demands increases 2 times more than during late gestation. Propionate is converted to glucose in the liver and it will be support lactose synthesis in the mammary gland. Propionate supplementation in this work provided better energetic supply and it is possible to consider, evaluating the milk yield. It was concluded that calcium propionate increased milk parameters like: milk protein, lactose and milk fat. Holstein cows fed calcium propionate had greater milk yield than other groups.
\end{abstract}

Keywords: calcium propionate, dairy cows, milk yield, milk compounds. 


\section{INTRODUCTION}

In the early lactation, dairy cows go through a period of negative energy balance because they do not intake enough food to supply the energetic demand of milk production [23]. In this period, dairy cows are susceptible to metabolic disorders, although has little evidence that milk production contribute to increase diseases occurrence [4]. Some alternatives to minimize metabolic disorders has been suggested as increase energy density in the diet of dry cows 21 days before the parturition and include additives in the diet pre and post-partum [11]. In this context, to increase energy density in diet it is used fat supplementation with calcium salts of fatty acid (CSFA). This supplementation has increased milk production of cows in confined systems receiving total mixed ration [26]. Calcium propionate (CP) is other additive used as energetic source. The propionate produced by ruminal fermentation is the main glycogenesis precursors during transition period [21]. Dairy cows fed $\mathrm{CP}$ showed higher levels of milk protein, extract non fatty and fat-corrected milk yield to $3.5 \%$ [1]. Complementing this work, seek to study de calcium acetate, other additive recently added to ruminants nutrition for reduce metabolic disorders in early lactation, because many tissues use acetate as energy source, in reaction that acetate is converted in Acetyl-coenzyme A within Krebs circle [25]. This statement is true because dairy cows in early lactation feeding CA had lower levels of $\beta$-hidroxibutirate (BHBA), concluding that calcium acetate were an important energetic source for dairy cows in early lactation [19]. The aim of this study was to measure the productive parameters in dairy cows fed calcium salts as energetic source.

\section{MATERIALS AND METHODS}

\section{Animals and experimental design}

The study was carried out in campus 2 of Universidade Paranaense, Umuarama, state of Paraná, Brazil. All procedures in this experiment were approved by the Ethical Committee of Universidade Paranaense. Eight Holstein cows, average body weight $540+/-30 \mathrm{~kg}$ and 5 years old were used. The animals were allocated in two latin square $(4 \times 4)$. One group had cows that were in their $7^{\text {th }}$ lactation day (early lactation). The other group had mid lactation cows ( 110 days). There were 4 treatments per group as follow: $\mathrm{T} 1=$ supplementation with $300 \mathrm{~g}$ of calcium acetate obtained from chemical reaction:
$\mathrm{Ca}(\mathrm{OH}) 2+2 .(\mathrm{CH} 3 \mathrm{COOH})=2 .(\mathrm{CH} 3 \mathrm{COO})$ $\mathrm{Ca}+2 . \mathrm{H} 2 \mathrm{O}$;

The pureness of calcium acetate were checked by the Chemistry Laboratory of Universidade Paranaense. $\mathrm{T} 2=$ supplementation with $200 \mathrm{~g}$ of calcium propionate $\left(\text { Propimpex }^{\circledR}\right)^{1}$; T3= supplementation with $300 \mathrm{~g}$ of calcium salts of fatty acids salts (Megalac$\left.\mathrm{E}^{\circledR}\right)^{2}$; $\mathrm{T} 4=$ Control group without supplementation. Animals were housed in individual pens, the supplementation was added to the concentrated feed offered once a day after morning milking. Animals were milked twice a day at 7 am and $5 \mathrm{pm}$. The amount of concentrate begun with $5 \mathrm{~kg}$ and were increased by $0.5 \mathrm{~kg} /$ day until reach the maximum of $8 \mathrm{~kg} / \mathrm{animal} /$ day and keep the proportion concentrate/bulky 40:60. Silage was given 3 times per day. Feed was weighted before serving and left over feed was calculated. Left over feed were sampled and subjected to bromatological analysis in the Laboratory of Bromatology of Escola Superior de Agricultura Luiz de Queiroz da Universidade de São Paulo. The diet was formulated based on NRC [23] (2001) recommendations for a $540-\mathrm{kg}$ cow to produce $20 \mathrm{~kg} /$ day of milk containing $3.4 \%$ of milk fat and $3.2 \%$ protein. Ingredients and chemical composition of the basal diet are shown in Table 1.

The trial period was 21 days whereas the initial period comprehends of 14 days for adaptation and the remaining 7 days were the sampling period. Samples were collected in the $1^{\text {st }}, 3^{\text {rd }}, 5^{\text {th }}$ and $7^{\text {th }}$ day of the sampling period.

\section{Measurements and collection of samples}

The animals were milked twice a day, the first milking at 07:00 am and the second milking at 05:00 pm. Milk samples were collected in plastic containers with potassium dichromate. These samples were sent to the Laboratory of Milk Analysis of the Paranaense Association of Breeders of the Holstein Breed for analysis of fat, protein, lactose and total solids through the infrared method. Throughout the experimental period, the daily production of the animals under study was recorded. The production of milk $(\mathrm{kg})$ was corrected to $3.5 \%$ fat using the formula PLA $3.5 \%=(0.432+\mathrm{kg}$ milk $)+(0.1623 \times \mathrm{kg}$ milk $\mathrm{x}$ fat content $)$ [5].

\section{Calculations and statistical analysis}

The results were obtained after statistical analysis with General Linear Models (GLM) of MiniTab $17^{\circledR}[28]$ with 5\% probability in reference to 
the following formula: $Y=\mu+\alpha+\beta+\gamma(\beta)+p+\varepsilon$, where $\mu$ is the general mean, $\alpha$ is the fixed effect of treatment, $\beta$ is the random effect of square, $\gamma(\beta)$ is the random effect of animal within square, $\mathrm{p}$ is the random effect of period and $\varepsilon$ is the random error. Comparisons between means were performed using Tukey test with $5 \%$ probability.

\section{RESULTS}

Milk protein was higher in CP and CG than CA and CSFA in early lactation (Table 2). During the mid-lactation, there was significant difference between CP and CSFA $(P<0.05)$. During mid-lactation, lactose levels was higher in CP group than CSFA (Table 2). Dairy cows fed CSFA during mid-lactation had lower levels of milk fat than other groups $(P<0.05)$. During early lactation, $\mathrm{CP}$ group had greater levels of milk fat than $\mathrm{CG}$ and CSFA groups $(P<0.05)$ [Table 2]. Total solids value in the early lactation were higher in $\mathrm{CP}$ group than CSFA group. During mid-lactation, this value were higher in $\mathrm{CP}$ and GC group than CSFA group (Table 2). During early lactation, dry matter intake (DMI) was lower in CP group (Table 2). During early lactation, fat-corrected milk yield were higher in CP group $(21,5 ; P<0.05)$ than other groups (Table 2). Moreover, fat-corrected milk yield in CA group were higher than CG and CSFA group (18,31 vs 15,67; $15,26)$. In the mid-lactation, CSFA group presented lower fat-corrected milk yield than other groups.

\section{DISCUSSION}

Dairy cows fed CP had greater values of milk protein than CA and CSFA. Greater supply of glucose or propionate stimulate milk protein production, the mechanism of this stimulation is unclear [2]. Milk protein is dependent on energy supply, and deficient energy intake reduces milk protein levels [32], this confirm the results found in this study. Studies reports that dairy cows fed calcium propionate had higher levels of milk protein $[1,20]$, the same results of our work. Calcium propionate provided enough energy supply and increased milk protein levels in this study.

The synthesis of lactose has influence in water absorption in mammary gland and lactose determine milk osmolarity. The lactose levels vary according blood glucose, somatic cells count and energy availability for physiological processes [9]. During mid-lactation, lactose levels of dairy cows fed CP was higher than other groups. Greater lactose concentration caused by feed intake is found rarely in literature [24], becoming very important the results found in this work. Glucose is the main precursor of lactose and propionate, produced by ruminal fermentation of carbohydrates, is the main precursor of glucose [14]. Dairy cows fed propionate had been tendency to lactose level be greater $(P<0.07)$, this trend is indicative of greater energy supply [24]. This statement corroborates the results found in the present study and propionate may be provided as a source of energy intake for cows during the mid-lactation.

Dairy cows fed CSFA during mid-lactation had lower levels of milk fat than other groups $(P<0.05)$ and during early lactation, milk fat of CSFA was lower than CP group. It is known that the milk fat is reduced by CSFA, the level of milk fat can reduced from 2.9 to $2.14 \%$ [22]. The microbial inefficiency to use the lipids as a source of growth triggers a series of alterations in the ruminal environment. One of the main deleterious effects of the inclusion of high lipid concentrations is the reduction in ruminal digestion of the fiber [7]. Thus, the amounts and proportions of volatile fatty acids (VFA) produced in the rumen are altered negatively, reducing the milk production and milk fat [30]. The increased of linoleic acid C18:1 trans-10 and C18:2 cis-12 concentration, decrease milk fat levels in dairy cows fed CSFA [8]. Intermediate fatty acids formation from rumen biohydrogenation reduced levels of milk fat in dairy cows fed CSFA [16].

The total solids content in milk represents the sum of all the constituents of milk and fat is the major responsible for its alteration. This statistical difference between the groups could be explained based on the fat levels of the $\mathrm{CP}$ and $\mathrm{CG}$ groups that were higher than those of the CSFA group, consolidating a higher value of total solids.

Feed intake is essential for animal nutrition because it determines the level of nutrients intake and, therefore, animal response. The feed intake is regulated and limited by the metabolic and physiological requirements of animals. Any reduction in voluntary feed intake has significant effect on production efficiency [18]. The amount of dry matter intake by animals depends on many factors, including levels of milk production, stage of lactation, environmental conditions, live weight, handling, type and quality of foods [3]. Dry matter intake (DMI) was lower in CP 
Table 1. Ingredient and chemical composition of the basal diet (in $\mathrm{g} / \mathrm{kg}$ dry matter).

\begin{tabular}{ccccc}
\hline Nutrient & CG & CA & CP & CSFA \\
\hline Ingredients g kg- & & & & \\
\hline Corn Silage & 800 & 792.7 & 795.2 & 792.7 \\
Corn grain & 117.6 & 117.6 & 117.6 & 117.6 \\
Soybean meal & 70 & 70 & 70 & 70 \\
Limestone & 1 & 1 & 1 & 1 \\
Sodium Clhoride & 1.4 & 1.4 & 1.4 & 1.4 \\
Minerals and Vitamins* & 10 & 10 & 10 & \\
Calcium Acetate & & 7.3 & & \\
Calcium Propionate & & & 4.8 & 7.3 \\
CSFA & & & & 372 \\
Nutrient & 368 & 372 & 371 & 473 \\
Dry matter g kg-1 & 476 & 473 & 475 & 108.9 \\
Neutral detergente fiber & 109.5 & 108.9 & 108.9 & 67.9 \\
Crude Protein & 68.28 & 67.90 & 68.1 & 30.7 \\
Total digestible nutrients & 24.66 & 24.5 & 24.6 & 3992 \\
Ethereal extract & 3995.2 & 3992 & 4000 & \\
NE (kcal g-1) & & & & \\
\hline
\end{tabular}

*Calcium 220 g/kg; Phosphorus 60 g/kg; Sulfur 20 g/kg; Magnesium 20 g/kg; Potassium 35 g/kg; Sodium 70 g/kg; Cobalt 15 mg/kg; Copper 700 mg/ $\mathrm{kg}$; Chrome $10.00 \mathrm{mg} / \mathrm{kg}$; Iron $700 \mathrm{mg} / \mathrm{kg}$; Iodine $40 \mathrm{mg} / \mathrm{kg}$; Manganese $1600 \mathrm{mg} / \mathrm{kg}$; Selenium $19 \mathrm{mg} / \mathrm{kg}$; Zinc $2500 \mathrm{mg} / \mathrm{kg}$; Vitamin A 400000 UI/kg; Vitamin D3 100000 UI/kg; Vitamin E 2400 UI/kg.

Table 2. Productive parameters of lactating dairy cows feeding energetic sources in the calcium salts forms.

\begin{tabular}{|c|c|c|c|c|c|c|c|c|}
\hline & \multicolumn{4}{|c|}{ Early Lactation } & \multicolumn{4}{|c|}{ Mid-lactation } \\
\hline & $\mathrm{CA}$ & $\mathrm{CP}$ & CSFA & $\mathrm{CG}$ & $\mathrm{CA}$ & $\mathrm{CP}$ & CSFA & $\mathrm{CG}$ \\
\hline Lactose $\left(\mathrm{g} \mathrm{L}^{-1}\right)$ & $4.49^{\mathrm{a}}$ & $4.37^{\mathrm{a}}$ & $4.40^{\mathrm{a}}$ & $4.39^{\mathrm{a}}$ & $4.31^{\mathrm{ab}}$ & $4.37^{\mathrm{a}}$ & $4.27^{\mathrm{b}}$ & $4.30^{\mathrm{ab}}$ \\
\hline Milk Protein $\left(\mathrm{g} \mathrm{L}^{-1}\right)$ & $2.98^{\mathrm{b}}$ & $3.12^{\mathrm{a}}$ & $2.99^{b}$ & $3.14^{\mathrm{a}}$ & $3.10^{\mathrm{a}}$ & $3.24^{\mathrm{a}}$ & $3.14^{\mathrm{a}}$ & $3.13^{\mathrm{a}}$ \\
\hline Milk Fat $\left(\mathrm{g} \mathrm{L}^{-1}\right)$ & $3.23^{\mathrm{ab}}$ & $3.47^{\mathrm{a}}$ & $2.84^{\mathrm{b}}$ & $3.04^{\mathrm{b}}$ & $3.23^{\mathrm{a}}$ & $3.34^{\mathrm{a}}$ & $2.83^{\mathrm{b}}$ & $3.50^{\mathrm{a}}$ \\
\hline Total Solids $\left(\mathrm{g} \mathrm{L}^{-1}\right)$ & $11.7^{\mathrm{ab}}$ & $11.96^{\mathrm{a}}$ & $11.20^{\mathrm{b}}$ & $11.49^{\mathrm{ab}}$ & $11.6^{\mathrm{ab}}$ & $11.92^{\mathrm{a}}$ & $11.20^{\mathrm{b}}$ & $11.89^{\mathrm{a}}$ \\
\hline DMI* (kg) & $15.43^{\mathrm{ab}}$ & $15.16^{\mathrm{b}}$ & $15.53^{\mathrm{a}}$ & $15.55^{\mathrm{a}}$ & $15.23^{\mathrm{a}}$ & $14.78^{\mathrm{a}}$ & $15^{\mathrm{a}}$ & $15.18^{\mathrm{a}}$ \\
\hline $\mathrm{FCM}^{* *}(\mathrm{~L})$ & $18.31^{\mathrm{b}}$ & $21.13^{\mathrm{a}}$ & $15.26^{\mathrm{c}}$ & $15.67^{\mathrm{c}}$ & $17.09^{\mathrm{a}}$ & $15.91^{\mathrm{a}}$ & $13.2^{\mathrm{b}}$ & $16.50^{\mathrm{a}}$ \\
\hline
\end{tabular}

"Dry matter intake. ${ }^{* *}$ Fat corrected milk $3.5 \%$.

group (Table 2) during early lactation. Propionate infusion in puerperal dairy cows decrease dry matter intake [29]. The hypophagic effect of propionate in puerperal cows is greater than cows in mid-lactation, as found in this study. This occurs because propionate may stimulate satiety by oxidation via conversion to Acetyl-Coenzyme A or if uptake by the liver exceeds the neoglycogenic flow. Lower dry matter intake in dairy cows fed CP is still controversial, because some studies report no difference in dry matter intake [15] and in others trend of higher dry matter intake in dairy cows supplemented with propionate [16]. It is necessary more studies to confirm this statement.

Dairy cows in early lactation has marked increased of nutrient requirements to support milk production [17]. Support milk lactose synthesis in the mammary gland is the one of responsible for increase of nutrients requirements. In this period, the glucose demands increases 2 times more than during late gestation [21]. Propionate produced from ruminal fermentation is quantitatively the greatest contributor to gluconeogenesis during the periparturient period [27]. 
In ruminants, propionate has been used as an energetic source and can act as metabolic mediator of nutritional status [15]. In our study, dairy cows fed CP had higher milk yield than other groups, what other authors have already found [1]. In contrast, other authors reported no difference in milk yield in dairy cows fed calcium propionate [13,15], but in one of this studies dairy cows received $\mathrm{CP}$ in three moments: at calving, $24 \mathrm{~h}$ after calving and 7 days after calving [13]. Propionate is converted to glucose in the liver and it will be support lactose synthesis in the mammary gland. Propionate supplementation in this work provided better energetic supply and it is possible to consider, evaluating the milk yield.

Volatile fatty acids is the main products of ruminal fermentation of carbohydrates [12] and acetate is the major end product of rumen fermentation in the cow [31]. Acetate oxidation rather than glucose plays the important role in energy metabolism in ruminant [12]. It is responsible for lipid synthesis in ruminants adipose and mammary gland and acetate supply could affected milk fat yield in lactating cows [31]. The greater fat-corrected milk yield found in CA group in this work, during early lactation; prove the importance of acetate in energy metabolism of dairy cows. Milk yield was higher in dairy cows that received infusion of acetate during 4 days [31], this corroborates with results found in this work. Theoretically, supply acetate improve milk yield because provides energy for dairy cows in early lactation and mammary gland can use blood glucose to produces lactose, increasing the milk production.

The diet energy concentration and consumption rate determine energy intake, which limit milk yield. CSFA supplementation has been used to increase energy concentration of dairy cows diet, although may interfere with ruminal metabolism by reducing the digestibility of the fiber, hampering the microbial attack and provoking toxic effects on certain microorganisms [3]. There is also the formation of intermediary fatty acids from biohydrogenation, which results in lower production and availability of fatty acids for milk and milk fat synthesis [6]. Literature confirmed this statement [6], but the addition of CSFA decrease milk yield in dairy cows fed high-quality forage [10]. This fact also helps explain the lower milk yield in CSFA group in this study.

\section{CONCLUSIONS}

Calcium propionate, despite reduced dry matter intake during early lactation, it increased milk yield in this study. The propionate supply increased milk protein, lactose and milk fat and total solids during early lactation. It demonstrates that calcium propionate is a good additive for use in dairy cows during early lactation. Calcium acetate increased milk yield during early lactation, could be other option to provide a dairy cows in this period of lactation, but, calcium acetate supplementation requires further investigation.

\section{MANUFACTURERS \\ ${ }^{1}$ Impextraco Latin America Com. e Ind. de Produtos para Nutrição Ltda. Curitiba, PR, Brazil. \\ ${ }^{2}$ Elanco Saúde Animal Ltda. São Paulo, SP, Brazil.}

Acknowledgements. We thank the Universidade Paranaense for granting the animals and the necessary structure for research and CAPES by scholarship.

Declaration of interest. The authors report no conflicts of interest. The authors alone are responsible for the content and writing of the paper.

\section{REFERENCES}

1 Alberton L.R., Fanin M., Oro M., Savanhago R. \& Martins W.D.C. 2013. Efeito da suplementação de vacas com propionato de cálcio na dieta sobre a glicemia, produção e composição do leite. Enciclopédia Biosfera. 17: 1202-1212.

2 Bajramaj D.L., Curtis R.V., Kim J.J.M., Corredig M., Doelman J., Wright T.C. \& Osborne V.R. 2017. Addition of glycerol to lactating cow diets stimulates dry matter intake and milk protein yield to a greater extent than addition of corn grain. Journal of Dairy Science. 100: 1-12.

3 Duarte L.M.D., Stumpf Junior W., Fischer V. \& Salla L.E. 2005. Efeito de diferentes fontes de gordura na dieta de vacas Jersey sobre o consumo, a produção e a composição do leite. Revista Brasileira de Zootecnia. 34(6): 2020-2028.

4 Drackley J.K. \& Cardoso F.C. 2014. Prepartum and postpartum nutritional management to optimize fertility in highyielding dairy cows in confined TMR systems. Animal. 8(1): 5-14.

5 Evans E.H., Yoston S.A. \& Binnendyk D.V. 1993. Numerous factors affect milk protein percentage. Feedstuffs. 15: $14-21$. 
6 Freitas-Júnior J.E., Rennó F.P., Silva L.F.P., Gandra J.R., Maturana-Filho M., Foditsch C. \& Venturelli B.C. 2010. Parâmetros sanguíneos de vacas leiteiras suplementadas com diferentes fontes de gordura. Ciência Rural.40(4): 950-956.

7 Goularte S.R., Ítavo L.C.V., Santos G.T., Ítavo C.C.B.F., Oliveira L.C.S., Favaro S.P., Dias A.M., Torres-Junior R.A.A. \& Bittar C.M.M. 2011. Ácidos graxos voláteis no rúmen de vacas alimentadas com diferentes teores de carboidrato na dieta. Arquivo Brasileiro de Medicina Veterinária e Zootecnia. 63(6): 1479-1486.

8 Harvatine K.J. \& Allen M.S. 2006. Effect of fatty acid suplements on milk yeld and energy balance of lactating dairy cows. Journal of Dairy Science. 89(3): 1081-1091.

9 Henao-Velásquez A.F., Múnera-Bedoya O.D., Herrera A.C., Agudelo-Trujillo J.H. \& Cerón-Muñoz M.F. 2014. Lactose and milk urea nitrogen: fluctuations during in Hosltein cows. Revista Brasileira de Zootecnia. 43(9): 479-484.

10 Hu Z.Y., Yin Z.Y., Lin X.Y., Yan Z.G. \& Wang Z.H. 2015. Effects of feeding fatty acid calcium and the interaction of forage quality on production performance and biochemical indexes in early lactation cow. Journal of Animal Physiology and Animal Nutrition. 99(5): 899-904.

11 Juchem S.O., Santos F.A.P., Imaizumi H., Pires A.V. \& Barnabé E.C. 2004. Production and blood parameters of Holstein cows treated prepartum with sodium monensin or propylene glycol. Journal of Dairy Science. 87(3): 680-689.

12 Kaneko J.J. 2008. Carbohydrate metabolism and its diseases. In: Kaneko J.J., Harvey J.W. \& Bruss M.L. (Eds). Clinical Biochemistry of Domestic Animals. 6th edn. San Diego: Elsevier, pp.45-80.

13 Kara Ç., Orman A., Udum D., Yavuz H.M. \& Kovanlikaya A. 2009. Effects of calcium propionate by different numbers of applications in first week postpartum of dairy cows on hypocalcemia, milk production and reproductive disorders. Italian Journal of Animal Science. 8(2): 259-270.

14 Lemosquet S., Raggio G., Lobley G.E., Rulquin H., Guinard-Flament J. \& Lapierre H. 2009. Whole-body glucose metabolism and mammary energetic nutrient metabolism in lactating dairy cows receiving digestive infusions of casein and propionic acid. Journal of Dairy Science. 92(12): 6068-6082.

15 Liu Q., Wang C., Yang W.Z., Guo G., Yang X.M., He D.C., Dong K.H. \& Huang Y.X. 2010. Effects of calcium propionate supplementation on lactation performance, energy balance and blood metabolites in early lactation dairy cows. Journal of Animal Physiology and Animal Nutrition. 94(5): 605-614.

16 MacNamara J.P. \& Valdez F. 2005. Adipose tissue metabolism and production responses to calcium propionate and chromium propionate. Journal of Dairy Science. 88(7): 2498-2507.

17 Mann S., Leal Yepes F.A., Overton T.R., Wakshlag J.J., Lock A.L., Ryan C.M. \& Nydam D.V. 2015. Dry period plane of energy: Effects on feed intake, energy balance, milk production, and composition in transition dairy cows. Journal of Dairy Science. 98: 3366-3382.

18 Maggioni D., Marques J.A., Rotta P.P., Zawadzki F., Ito R.H. \& Prado I.N. 2009. Ingestão de alimentos. Semina. 30(4): 963-974.

19 Martins W.D.C., Cunha S.H.M., Boscarato A.G., Lima J.S., Esteves-Junior J.D., Uliana G.L.T., Pedrini M.T. \& Alberton L.R. 2018. Blood parameter of lactating dairy cows fed calcium salts as energetic sources. Acta Scientiae Veterinariae. 46: 1599. 7p. dx.doi.org/ 10.22456/1679-9216.85932.

20 Matras J., Klebaniuk R. \& Kovalczuk-Vasilev E. 2012. Impact of glucogenic additive in transition dairy cow diets varying ruminal starch degrability on yeld and composition of milk and reproductive parameters. Czech Journal Animal Science. 57(7): 301-311.

21 McCarthy M.M., Piepenbrink M.S. \& Overton T.R. 2015. Associations between hepatic metabolism of propionate and palmitate in liver slices from transition dairy cows. Journal of Dairy Science. 98(10): 7015-7024.

22 Medeiros S.R., Oliveira D.E., Aroeira L.J.M., McGuire M.A., Bauman D.E. \& Lanna D.P. 2010. Effects of dietary supplementation of rumen-protected conjugated linoleic acid to grazing cows in early lactation, Journal of Dairy Science. 93(3): 1126-1137.

23 National Research Council - NRC. 2001. Nutrient Requeriments of Dairy Cattle. 7th edn. Washington D.C.: NRC, 381p.

24 Patton R.S., Sorenson C.E. \& Hippen R. 2004. Effects of dietary precursors and fat on feed intake and carbohydrate status of transition dairy cows. Journal of Dairy Science. 87(7): 2122-2129.

25 Osorio J.H. \& Vinazco J. 2010. El metabolismo lipídico bovino y su relación com la dieta, condicion corporal, estado productivo y patologias asociadas. Biosalud. 9(2): 52-56.

26 Rabiee A.R., Breinhild K., Scott W., Golder H.M., Block E. \& Lean I.J. 2012. Effect of fat additions to diets of dairy cattle on milk production and components: A meta-analysis and meta-regression. Journal of Dairy Science. 95(6): 3225-3247. 
27 Reynolds C.K., Aikman P.C., Lupoli B., Humphries D.J. \& Beever D.E. 2003. Splanchnic metabolism of dairy cows during the transition from late gestation through early lactation. Journal of Dairy Science. 86(4): 1201-1217.

28 Ryan B.F. \& Joiner B.L. 1994. Minitab handbook. 3rd edn. Belmont: Duxbury Press, 448p.

29 Stockes S.E. \& Allen M.S. 2012. Hypophagic effects of propionate increase with elevated hepatic acetyl coenzyme A concentration for cows in the early postpartum period. Journal of Dairy Science. 95(6): 3259-3268.

30 Theurer M.L., Block E., Sanchez W.K. \& McGuire M.A. 2009. Calcium salts of polyunsatured fatty acids deliver more esencial fatty acids to the lactating dairy cows. Journal of Dairy Science. 92(5): 2051-2056.

31 Urrutia N.L. \& Harvatine K.J. 2017. Acetate Dose-Dependently Stimulates Milk Fat Synthesis in Lactating Dairy Cows. The Journal of Nutrition. 147(5): 763-769.

32 Wittwer F. 2000. Marcadores bioquímicos no controle de problemas metabólicos nutricionais em gado de leite. In: Gonzáles F.H.D; Barcelos J., Patiño H.O. \& Ribeiro L.A.O. (Eds). Perfil Metabólico em Ruminantes. Seu uso em Nutrição e Doenças Nutricionais. Porto Alegre: UFRGS, pp.53-62. 